\title{
Using hydrochemical and environmental isotope data to characterize the thermal reservoir of the Upper Jurassic aquifer in the South German Molasse Basin on the Pleistocene timescale
}

THEIS WINTER AND FLORIAN EINSIEDL

Technical University of Munich

Presenting Author: theis.winter@tum.de

The Upper Jurassic aquifer within the South German Molasse Basin (SGMB) is the most important exploration horizon for geothermal energy supply in Bavaria. This aquifer is characterized by a heterogeneous geology which is composed of karstic features and fault-zones. The chemical evolution of the aquifer was intensively studied over the last couple of years and it was found statistically that the groundwater consists of three different water types and may be partially recharged at the southern margin of the SGMB.

In this study we are focussing on the water chemical composition of the thermal water in the southern part of the basin and also determined the apparent groundwater ages of the Upper Jurassic aquifer in this region.

Generally, groundwater in this area is of $\mathrm{Na}-\mathrm{HCO}_{3}-\mathrm{Cl}$ type but partially show $\mathrm{Ca}^{2+}$ and $\mathrm{Mg}^{2+}$ concentrations below the expected range of collected groundwater within the basin. The stable water isotope values ranged between -10.66 to $-11.76 \%$ for $\delta^{18} \mathrm{O}$ and -85 to $-86.06 \%$ for $\delta^{2} \mathrm{H}$ and may indicate infiltration of meteoric water under cold climate conditions.

The link between hydrochemistry data, stable water isotopes $\left(\delta^{18} \mathrm{O} / \delta^{2} \mathrm{H}\right)$ with apparent groundwater ages from ${ }^{14} \mathrm{C}_{\mathrm{DOC}}$ and ${ }^{14} \mathrm{C}_{\mathrm{DIC}}$ and infiltration temperatures from the noble gas thermometer combined with ${ }^{81} \mathrm{Kr}$ from literature may indicate that vertical leakage, through fracture zones for example, might have a considerable impact on the water chemical and isotopic composition of the thermal water reservoir of SGMB. 